\title{
Implementation of Adiwiyata Program to Build Environmental Awareness
}

\author{
Rabiatul Adawiah \\ Faculy of Teacher Training and Educaion, Lambung Mangkurat University, Indonesia
}

\begin{abstract}
This study aims to find out the implementation of environmental caring and cultured (Adiwiyata) school program in Balangan Regency; (2) students' attitude and behavior regarding environmental management and protection. This study uses a qualitative approach; the instruments used were interviews, observations, and questionnaires. The data analysis used an interactive model analysis of Miles and Huberman. The results show that the implementation of environmental caring and cultured school program in Balangan generally runs well, especially for environmental school policy, participatory based environmental activities, and management of environment supporting facility, nevertheles for environment based school curriculum development; there are some schools that have not implemented it holistically. Some teachers do not understand how to integrate the environment values into subject. Based on the findings of the students' questionnaire, students' attitude and behavior dealing with environmental management and protection are those that show $38.5 \%$ or very good attitude, $45 \%$ which means good attitude, and $12.5 \%$ referring to fairly good attitude, and $4 \%$ showing bad attitude.
\end{abstract}

Keywords: implementation, Adiwiyata, environmental awareness

\section{INTRODUCTION}

The environment is the one thing consisting of living things and other components in it. This view is reinforced by Soemarwoto (2009) that the environment is all objects and conditions that exist in the space occupied and affecting the life. Kaushik (2010) states that the environment is a number of totalities of water, air, land, and relations of interaction in it as well as interactions with humans, other creatures and with various other objects. Wiryono (2013) also said that the environment is a combination of all things around us that can affect our lives. Therefore, the quality is important to be maintained and this is not only the responsibility of the government, but the responsibility of all people.

The important thing that determines the quality of the environment is human behavior. If human behaves well and cares about the environment, the quality of the

Correspondence Author: Rabiatul Adawiyah, Faculy of Teacher Training and Education, Lambung Mangkurat University, Indonesia Corresponding Email:

rabiatuladawiyah@ulm.ac.id environment will be maintained, and vice versa. The natural disasters, such as floods, landslides, forest fires are the effects of human indifference towards the environmental preservation. The human' behavior of littering or disposing of garbage in the river, logging trees without rehabilitation, and burning forests is an example of behavior that can damage environmental sustainability.

Changing the pattern and behavior of the community in order to have the postive attitude of caring for the environment is not an easy task. Uno and Mohamad (2011) mention that making people aware of the lack of understanding the meaning of environmental quality for the preservation of humanity is the heavy task. However, this does not mean that it cannot be solved because we are sure that there is way of solving that problem. One of them is through school as a space to build an educated life process. Yafei (2006) says there are many ways that can be done to provide a good understanding of the environment for each individual. One of them is through formal and non-formal education, from kindergarten to higher education. Onder (2006) stated that 
environmental education offers a long-term solution to environmental problems.

Hamzah (2013) asserts that environmental education is a need to realize civil society. Krech and Crutcfield (Mutaqinah, 2015) stated that the level of public awareness of environment occurs as a result of the development of understanding of the environment itself or as a result of changes in the needs of values that are embraced by attitudes and individual characteristic.

So that environmental awareness can be formed early on, a joint agreement between Minister of Environment and Minister of National Education was signed on June 3, 2005. The realization of the agreement on February 21, 2006 was declared as the Adiwiyata Program, which is environmental caring and cultured school. Adiwiyata is applied in education because it is easier to learn and environmental education itself applies all knowledge and various norms and ethics to achieve the ideals of sustainable development. Consequently, eco-education is dependent on the philosophy of nature and life, materialized in a global strategy, such as that of durable and knowledge-based development, facilitating the harmonization of various public policies launched by contemporary organizations and authorities (Iovan, 2014).

According to Widaningsih (Landriany, 2014), formally environmental education is one of the rational alternatives for incorporating environmental education into the curriculum. Enviromental education dealing with Adiwiyata program is important to change the green of school community (Tompodung, Rushayati, and Aidi, 2006). Environmental education is one of the important factors in the success of environmental management and is a very important means of producing human resources that can implement the principle of sustainable development. According to Nurjhani and Widodo (Landriany, 2014), environmental education is needed and must be given to children early so that they understand the environment and do not damage the ecosystem of the environment. Environmental education is a valuable tool, capable of freeing man from the living circle of consumerism and putting him on the axis of his own existence again (Pinto and Mamed, 2016).

Ilona et all (2016) define environmental education as the learning space to build environmental awareness in which all animate and inanimate things complement each other. All animate and inanimate things consisting of human being, plants, animals, water, soil, and air are united and they take care of themselves as the unity. Environmental education also can be viewed so that the people can understand the environmental balance and their role in it, form opinions as to how they can live in harmony with the environment and acquire necessary skill for active and responsible participation (Erol and Gezer, 2006). Muhaimin adds that environmental education to build enviromental awareness should be built through enhancing the local environmental issues found in everyday life. Schools cultivate environmental competence through the formation of habits, role modeling, and school behavior and culture (2015). Neaman et all (2018) strengthens this view that environmental education should be supported with prosocial behavior in which social behavior aims to form the self capacity to be strong in enviromental awareness.

At present there are many schools running environmental caring and cultured school program, including in Balangan Regency, both at the primary and secondary levels. Schools that run the Adiwiyata program have the potential to create future generations who care about the environment. However, to find out whether school citizens, especially students, have good attitude towards environmental protection and management after the program is implemented, it is necessary to do a study. The purpose of this study is to find out the implementation of environmental caring and cultured (Adiwiyata) school program in Balangan 
Regency; (2) students' attitude and regarding environmental management and protection.

\section{METHODOLOGY}

This study used a qualitative approach with the principle of being able to reveal, describe real events in the field, and reveal hidden values from this research. This study also stands on the critical attitude towards descriptive information and seeks to maintain the integrity of the object under study. In this study, the researcher is in a position as key instrument (Lincoln and Guba, 1985).

This research was conducted in Balangan Regency, South Kalimantan Province. Not all schools in Balangan Regency carry out the Adiwiyata program. Therefore, the school used as the research location is the school that has implemented the Adiwiyata program. From the eight sub-districts, there are three sub-districts designated as research locations representing the upper, middle and lower regions, namely Juai District, South Paringin District, and Paringin District.

In this qualitative research, the researcher herself is the main instrument involved in the research location and is tasked with collecting information through observation and interviews. Interview was conducted in an open and unstructured manner. To facilitate the data collection, the researcher used field notes, tape recorders, photo cameras, and interview guidelines to support the process of data collection.

Observation was also used to observe the condition of school facilities and infrastructure carrying out the Adiwiyata program and questionnaire aimed at knowing students' attitudes regarding the environment. The data analysis used technical interactive model analysis from Miles and Huberman. In this model, the researcher moved on three components, namely data reduction, data presentation, and conclusion (Miles and Huberman, 1992).

\section{RESULTS}

\section{Implementation of environmental caring and cultured (Adiwiyata) school program in Balangan Regency}

\section{Environmental school policy}

To realize environmental caring and cultured school, the presence of a school management model supporting the implementation of environmental education by all school members in accordance with the basic principles of the participatory and sustainable Adiwiyata program is necessary and environmental school policy is the basis for implementation.

One of the requirements to become an Adiwiyata school or get an Adiwiyata award must apply environmental school policy. School policy that is environmental can be seen from the school vision and mission containing the environmental values. Based on the result of observation and interview, all schools that implement the Adiwiyata program have included environmental elements in their vision and mission. The formulation of the vision and mission consiting environmental element is carried out by the Adiwiyata Team formed in each school. Some schools deliberately display their vision and mission in front of the main door of the school so that they are seen.

Another requirement is that the school needs to create healthy and clean environment condition. To create the healthy and clean environment, the school schedules the alternating cleaning picket for all students, implements clean Friday classes for all school citizens, plants trees and various flowers and other ornamental plants, provides garbage types according to types, and establishes a waste bank. There are even schools that require certain classes to bring lunch from home. By bringing lunch from home, this will guarantee health and can reduce the amount of garbage carried from outside the school. 
Another policy is to integrate Adiwiyata program into subjects. There are even schools whose local content is environmental education, such as SMKN PP Balangan. It is in line with what Jabłońska (2017) says that educating proper attitudes towards the surrounding nature must be based on sound knowledge gained, supported by observation, experience and experiment. Teaching conducted at all levels environmental science should be based not on boxed knowledge, but on causal thinking skills. In addition, there are some schools that allocate and use funds for activities relating to environmental management and protection.

\section{Development of Environment Based School Curriculum}

Schools that care about environment must be strengthened with environmental knowledge. One way to improve this knowledge is by implementing environment based curriculum. The established school policy will be seen in the implementation of the school curriculum where the teachers who teach in Adiwiyata schools must be able to integrate environmental caring and cultured values into all the subjects taught. Skladanovska and Iliushina (2016) state that the cultural approach in implementing enviromental values into school environment is an important means to improve the level of ecological culture of society and quality of life, and to maintain a balance in nature and the balanced development of the regions of our country.

The result of this study indicates that there are several schools that have succeeded in integrating the environmental values well into subjects, such as SDN Paringin Selatan 1, SMPN Paringin 4, and SMKN PP Paringin. In these schools, the environmental caring and cultured based curriculum program is really well implemented. All teachers have integrated it into all subjects both through methods, models, and learning techniques. One of the efforts made by the principal so that all teachers can integrate the environment into learning is always motivating the teachers to find out the teaching strategy through internet. Teacher's creativity and innovation in teaching learning process is needed and required.

However, there are also some schools that have not succeeded in integrating the environmental values into subjects, such as SDN Jual, SMAN 1 Juai, dan SMPN 1 Juai. This is because they do not understand how to integrate environmental education into subjects. Some of the teachers think that only science subject can be integrated with the environment. The teacher's lack of understanding of integrating environmental education into the subject is because the teacher has never received education and training program from the Education Office, the Environment Service or schools that are already as Adiwiyata School in the national level.

\section{Participatory Based Environmental Activity}

Creating a clean environment requires the participation of all school citizens where environment based programs are a necessity. In some schools, environmental activity has been carried out well such as SDN 1 Juai by holding a clean Friday on a weekly basis where all school citizens are obliged to be involved in the cleaning process at school. Every day each class is made an alternate schedule to care for the plants in the school, sweep the yard, pick up, and dispose of the garbage in its place. The same thing was done at SMAN 1 Juai where every Saturday all school members carried out joint activities to maintain the cleanliness of the school environment, such as planting trees, caring for school parks, toga, and making garbage banks.

In other schools, such as SDN Paringin Selatan 1, SMPN 4 Paringin, dan SMKN PP Paringin, they carry out various events dealing with the environment on environmental day, earth day, water day, and tree day. In addition, they also participated in various environmental activities organized 
by parties outside the school and developed extracurricular activities such as Sispala, PMR, and Scouts. The Chairman of the Adiwiyata Team at Paringin Selatan Elementary School 1 said that it was important to form the Adiwiyata Task Force with the task of spreading the concept of virus. The intended virus is not a disease, but it means that the spirit of caring for the environment can be spread from students to other students, from teachers to other teachers, and from educational staff to other education personnel.

\section{Management of Supporting Facilities for Caring Environment}

The availability of facilities in order to realize a school that cares about the environment is very important. By having facilities that care about the environment, schools can overcome environmental problems at school. To achieve the goal of overcoming these problems, this requires a good management process. In a number of schools as the research locations such as SDN 1 Juai, SDN Paringin Selatan 1, SMPN 4 Paringin, dan SMKN PP Paringin, they have provided several types of environmental care facilities both to overcome problems and to support learning. One of them is green house, compost house, biopori, infiltration well, and Adiwiyata garden.

In addition, the school also strives to create a healthy canteen where SMPN 4 Paringin and SDN Paringin Selatan 1 do so. To support the Adiwiyata program, the school canteen must be managed to become a healthy and environment caring canteen. To achieve this goal, the school has established a partnership with the community health center or clinic to provide input on managing a healthy canteen. In managing a healthy canteen, the school also implemented the Adiwiyata canteen standard policy where the policy was intended to prohibit selling cigarettes, prohibiting the use of excessive flavoring, not selling foods containing preservatives, dyes, sweeteners that endanger health, not selling drinks packed in plastic bottles / cups, and does not serve students when teaching learning activity takes place, except students who take breaks during sports subject.

Based on the researcher' observation, the management of infrastructure facilities that care about the environment in schools has been very good, which is shown from planting of neatly arranged plants, maintaining green house, managing waste bank, the availability of school park, leaf trash destroyer, vehicle for the cleanliness of the school environment, clean toilet, clean and hygienic school canteen, the availability of hand washing places in front of each class, garbage bin in accordance with the regulation issued by the Balangan Regency Environmental Service. While at SMPN 1 Juai and SMAN 1 Juai, the management of facilities and infrastructure is not well done, such as lack of maintenance of toga, unavailability of green house, less optimal utilization and disposal of waste banks, absence of hand washing places in every class and garbage place that still uses the old procedure.

\section{Overview of Students' Attitude and Behavior about Environmental Management and Protection}

Adiwiyata general goal is to establish a caring and cultured school in which school citizens are required to be able to participate actively and they carry out environmental conservation and sustainable development efforts for the benefit of present and future generations. In addition, Adiwiyata also aims to create good condition for the school as a learning space and awareness of the school community so that the school citizens can take responsibility in efforts to save the environment and sustainable development.

To find out the students' attitude and behavior as the school citizens, the research team distributed questionnaires to 200 students who were selected as research 
samples. The description of students' attitude the figure below: relating to the environment can be seen in

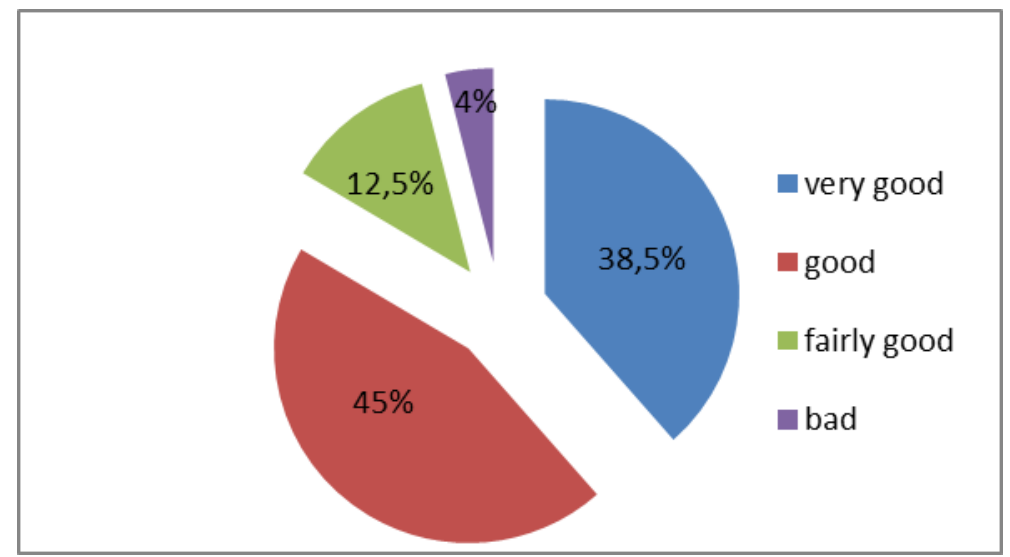

Based on the figure above, students' attitude dealing with environmental management and protection are $38.5 \%$ as very good attitude, $45 \%$ as good attitude, $12.5 \%$ as fairly good attitude, and $4 \%$ as bad attitude.

\section{DISCUSSION}

\section{Implementation of Environmental Caring and Cultured School Program in Balangan Regency}

The environmental school policy in Balangan Regency was formulated by the Adiwiyata team that was formed in each school. In the initial stage, the planned programs to be carried out are arranged for one year. The programs are related to determine the environmental school policy including vision and mission, structure of the curriculum containing environmental values, socialization of Adiwiyata program, an inventory of environmental facilities and infrastructure and the preparation of schedules of environmental actions. All policies are socialized during the ceremony, school orientation period for students' entrance, and other school programs.

The success of implementing a policy is influenced by several factors. It is in line with what Rahman (2009) said that there are three factors that determine failure and success in implementing policies, namely policy maker, the executor team of policy, and the organizational systems of the executor team. It means that the enviromental policy was formulated by Adiwiyata team established in each school to be the new regulation and must be obeyed by all school citizens.

Some of the schools studied have also applied an environment based curriculum. According to Budi Adam (2014), an environment based curriculum can be simply implemented by delivering environmental material through a diverse curriculum to provide an understanding of the environment that is associated in daily life. Environmental based curriculum developed by schools in an effort to protect and manage the environment can be integrated with any subjects. Noelaka (2008) says that examples of environmental material that can be integrated into school subjects are hrough subjects in physics, chemistry, biology, cultural anthropology, and geography.

Other implementations that have been implemented are participatory based environmental progam. The participatory environmental program is carried out in accordance with the Adiwiyata school standards determined by Ministry of Environment and Ministry of Education. In 
Adiwiyata guide book (2012: 21), the first standard of activity is to maintain school building. The second is to use land and facilities according to environmental rules. The third is the creativity and innovation of school citizens to protect and manage the environment. What has become the standard above has mostly been implemented well. Another thing that was implemented was the development of environment based extracurricular programs. According to AP lecturer Team (2012), the extracurricular programs are all activities that have been determined in the curriculum and their implementation is carried out outside the school hour. The extracurricular activities in schools are divided into schedules outside of learning. The aim is to instill the character of environmental care with students. According to Ministry of National Education document (2010), character education is instilled from good habits so that students can understand which good and wrong are, are able to experience good values, and can implement them.

In order to support the Adiwiyata program, almost all schools also provide environmental caring facilities. The procurement of environmental caring facilities at school is carried out by direct purchase and grant from several agencies that have collaborated in the Adiwiyata program. School facilities from the purchase are adjusted to Adiwiyata standards, while the facilities from grant have been determined and adjusted by the relevant agencies. The environmental caring facilities from the purchase and grant include waste bin, garbage cart, horticulture plant, horticulture plant, and banners on the list of environmental themes, the construction of green house, compost house, and pool. The source of environmental caring fund comes from the special allocation of Adiwiyata fund which are included in the school budget and also from the CSR fund of mining companies in Balangan Regency. The fund allocation is also used to manage facilities and infrastructure to care for school environment. Prihatin (2011) states that the procurement of facilities and infrastructure in the Adiwiyata program can be done by purchasing, receiving grants, accepting use right, exchanging and so on.

\section{Students' attitude and behavior about Environmental Management and Protection}

Adiwiyata School is a school that has carried out various programs to create responsible school citizens for protecting and managing the environment. Based on the results of the study, the Adiwiyata program run by schools had a positive impact on students' attitude and behavior dealing with environmental management and protection. This can be seen from the results of the students' questionnaire which shows $38.5 \%$ for very good attitude, $45 \%$ for good attitude, and $12 \%$ for fairly good attitude. It means that students' care for the environment is good. This relates to various policies implemented by schools and one of them is integrating the value into subjects. By integrating it in subjects, this will increase students' knowledge about the environment. This is reinforced by Neolaka's view (2008) that environmental care can be obtained through environmental education.

The results of this study are in line with some of the results of previous studies and one of them is Saragih's research (2012) suggesting that there is Adiwiyata program positive influence towards students' cognitive, affective, and psychomotor environment. The result of other study was also delivered by Manurung (2011) presenting the result of the study that the Adiwiyata program implemented at SDN Panggang 04 Jepara had developed a caring character for the school citizens. This can be seen through activities such as planting and caring for plant, sorting and disposing of waste, saving water, electricity and paper usage.

Another study by Mulyana (2009) also found that environmental education carried 
out in environmental caring and cultured school was considered effective to instill the care for preserving natural resources and environment. In other words, the rnvironmental education can be defined as a means to reestablish interpersonal and mannature relationships in order to prepare political citizens concerned with environmental protection and the assurance of the most fundamental right: the right to life itself (Kury, 2010).

The results of this study are in accordance with what was delivered by Landriyani (2014) that the environmental education is formally one of the rational alternatives for incorporating environmental education into the curriculum. The environmental education is one of the important factors in the success of environmental management and is a very important means of producing human resources that can implement the principle of sustainable development. Nurjhani and Widodo (Landriyani, 2014)) also stated environmental education is needed and must be given to children early so that they understand the importance of keeping environment. Iswari and Utomo (2017) say that Adiwiyata is a program that aims to create responsible school citizens to keep and manage the environment.

\section{CONCLUSION AND RECOMMENDATION}

The implementation of environmental caring and cultured school program in Balangan Regency generally runs well, especially for environmental school policy components, participatory based environmental activities, and management of environmental supporting facilities. Nevertheles for environment based school curriculum development, there are some schools that have not implemented it hollistically. Some teachers do not understand how to integrate the environmental values into subject.

Based on the findings of the questionnaire, students' attitude dealing with environmental management and protection were $38.5 \%$ as very good attitude, $45 \%$ as good attitude, and $12.5 \%$ as fairly good attitude, and $4 \%$ as bad attitude.

Based on the results of this study, it is recommended that the relevant institutions with the authority should provide the continuous assistance towards schools running the Adiwiyata program; (2) making schools that have already been successful as Adiwiyata schools in provincial and national level to provide assistance to other schools; and (3) involving students' parents to participate in fostering the character of caring for students so that what is applied in school can also be implimented at home.

\section{REFERENCES}

Erol, G.H., \& Gezer, K. (2006). Prospective of Elementary School Teachers' Attitudes toward Environment and Environmental Problems. International Journal of Environmental and Science Education, 1(1), 65-77.

Budi Adam, Ahmad Fajarisma (2014). Analisis Implementasi Kebijakan Kurikulum Berbasis Lingkungan Hidup Pada Program Adiwiyata Mandiri di SDN Dinoyo Malang. Jurnal Kebijakan dan Pengembangan Pendidikan, 2(2), 166173.

Hamzah B. Uno and Mohamad Nurdin. (2011). Belajar dengan Pendekatan PAILKEM. Jakarta: PT. Bumi Aksara.

Hamzah, Syukri. (2013). Pendidikan Lingkungan: Sekelumit Wawasan Pengantar. Bandung: Refika Aditama.

Iovan, Marţian. (2014). Eco-Education: A Required Element of Public Policies for Sustainable Social and Economic Development. Academicus: International Scientific Journal, MMXIV(9), 14-28. doi: 10.7336/academicus.2014.09.01

Ilona, Żeber-Dzikowska; Jarosław, Chmielewski; and Mariola, Wojciechowska. (2016). Ecological and environmental education in the ethical context. Environmental Protection and 
Natural Resources, 27(2), 44-47. doi: 10.1515/oszn-2016-0011

Jabłońska, Małgorzata Falencka. (2017). Environmental Protection and Education System in Poland. Ecological Engineering, 18(5), 36-39. doi: 10.12912/23920629/76228

Kaushik, Anubha dan C.P. Kaushik. (2010). Basic of Environment and Environment. New Delhi: New Age International.

Kementerian Pendidikan Nasional. (2010). Pengembangan Pendidikan Budaya dan Karakter Bangsa Pedoman Sekolah. Jakarta: Badan Penelitian dan Pengembangan, Pusat Kurikulum.

Kury, Karla Aguiar. (2010). Environmental education and citizenship. Boletim do Observatório Ambiental Alberto Ribeiro Lamego, 3(1), 107-116. doi: $10.5935 / 2177-4560.20090005$

Landriany, Ellen. (2014). Implementasi Kebijakan Adiwiyata dalam Upaya Mewujudkan Pendidikan Lingkungan Hidup di SMA Kota Malang. Jurnal Kebijakan dan Pengembangan Pendidikan, 2(1), 82-88.

Lincoln, Yvonna S., dan Egon G. Guba. (1982). Effective Evaluation, Improping the Evaluation Result Trough Responsive and Naturalistic Approach. California: Jossey-Bass Publisher.

Manurung, Yupiter L. (2011). Program Adiwiyata dalam Pengelolaan Lingkungan Sekolah (studi kasus SDN Panggung 04 Kecamatan Jepara Kabupaten Jepara Provinsi Jawa Tengah). Tesis (tidak diterbitkan). Semarang: PPS Universitas Diponegoro.

Mulyana, Rahmad. (2009). Penanaman Etika Lingkungan melalui Sekolah Peduli dan Berbudaya Lingkungan. Jurnal Tabularasa, 6(2), 175-180.

Miles, Mathew B., dan A. Michael Huberman. (1992). Analisis Data Kualitatif. Penerj: Tjetjep Rohendi Rohidi. Jakarta: Universitas Indonesia Press.

Muttaqimah. (2015). Evaluasi Program Sekolah Berbudaya Lingkungan
(Adiwiyata) Mandiri Tingkat SMP Se Jawa Barat. Disertasi (tidak diterbitkan). Jakarta: Program Pascasarjana Universitas Negeri Jakarta.

Muhaimin. (2015). Implementasi Model Pembelajaran Berbasis Masalah Lokal dalam Mengembangkan Kompetensi Ekologis pada Pembelajaran IPS. Sosio Didaktika: Social Science Education Journal, 2(1), 12-21. doi: 10.15408/sd.v2i1.1409

Neolaka. (2008). Kepedulian Lingkungan. Jakarta: Reneka Cipta.

Neaman, Alexander; Otto, Siegmar; and Vinokur, Eli. (2018). Toward an Integrated Approach to Environmental and Prosocial Education. Sustainability, 10(583), 1-11. doi: 10.3390/su10030583

Onder, S. (2006). Study of Awareness and Behavior in Regard to Environmental Issues among Selcuk University Students in Kongo, Turkey. Journal of Applied Sciences, 6(2), 347-352. doi: 10.3923/jas.2006.347.352

Prihatin, Eka. (2011). Manajemen Peserta Didik. Alfabeta: Bandung

Pinto, Dayla Barbosa and Mamed, Danielle de Ouro. (2016). Enviromental Education as a Response to Chaos SocioEnvironmental in the Context of Risk Society. Revista de Pesquisa e Educação Jurídica, 2(2), 1-15. doi: 10.26668/IndexLawJournals/25259636/2016.v2i2.1258

Rahman, Arif. (2009). Ideologi Pendidikan Lingkungan. Yogyakarta: Laksabang Mediatama.

R. Iswari, and S. Utomo. (2017). Evaluasi Penerapan Program Adiwiyata Untuk Membentuk Perilaku Peduli Lingkungan di Kalangan Siswa (Kasus: SMA Negeri 9 Tangerang Selatan dan MA Negeri 1 Serpong). Jurnal Ilmu Lingkungan, 15(1), 35-41. doi: 10.14710/ji1.15.1.35-41

Saragih, Andar Abdi. (2012). Pengaruh Program Adiwiyata terhadap Kognitif, Afektif dan Psikomotorik Lingkungan Hidup Siswa Sekolah Dasar di Kota Medan (Studi Kasus di SD Swasta Pertiwi 
dan SDN 06 Kecamatan Medan Barat). Tim Dosen AP. (2012). Manajemen Tesis (tidak diterbitkan). Medan: Pendidikan. Alfabeta: Bandung.

Pasacasarjana Universitas Sumatera Utara Tompodung, Tirza Carol Gracia; Rushayati, Medan.

Soemarwoto, Otto. (2009). Analisis Siti Badriyah; and Nur, M. Nur. (2006).

Perilaku Ramah Lingkungan terhadap Mengenai Dampak Lingkungan. Perilaku Ramah Lingkungan Warga Yogyakarta: Gadjah Mada University Sekolah di Kota Depok. Journal of Press.

Natural Resources and Environmental

Skladanovska M. H. and Iliushina K. O. (2016). Ecotourism As Way of Development of Ecological Culture of Modern Society. Visnik Pridniprovs'koï Deržavnoï Akademï Budivnictva ta Arhitekturi, 1(12), 67-71. Management, 8(2), 170-177. doi: 10.29244/jpsl.8.2.170-177

Wiryono. (2013). Pengantar Ilmu Lingkungan. Bengkulu: Pertelon Media. Yafie, Ali. (2006). Merintis Fiqh Lingkungan Hidup. Jakarta: Ufuk Press. 